\title{
Home Automation Berbasis Gesture Control Menggunakan Motion Processing Unit
}

\author{
Hartono', Kiki Prawiroredjo ${ }^{2}$ \\ 1,2,Program Studi Teknik Elektro, \\ Fakultas Teknologi Industri, \\ Universitas Trisakti, Jakarta \\ 1hartonoesc@gmail.com, ${ }^{2}$ kiki.prawiroredjo@trisakti.ac.id
}

\begin{abstract}
Abstrak
Home automation dengan pengenalan isyarat gerakan tangan dapat memberi kemudahan kepada pemilik rumah untuk mengontrol peralatan elektronik rumahnya terutama kepada para penyandang disabilitas yang memiliki keterbatasan untuk berjalan. Pada penelitian sebelumnya, perangkat pembaca isyarat berupa sarung tangan yang dilengkapi sensor akselerometer dan giroskop. Perangkat tersebut kurang fleksibel saat digunakan untuk melakukan aktivitas lain secara bersamaan sehingga dibutuhkan perangkat yang lebih wearable. Pada penelitian diajukan sebuah home automation system dengan pengenalan isyarat gerakan tangan menggunakan Motion Processing Unit (MPU). Perangkat dibuat dalam bentuk jam tangan digital sehingga lebih praktis saat digunakan. Sensor MPU akan mendeteksi isyarat gerakan tangan dimana setiap isyarat gerakan diproses oleh Arduino Nano dan didefinisikan sebagai suatu perintah yang akan dikirim ke perangkat penerima melalui modul frekuensi radio. Berdasarkan hasil pengujian, perangkat yang dibuat dapat mengontrol peralatan elektronik rumah dengan isyarat gerakan tangan sesuai spesifikasi yang diinginkan dengan nilai error sebesar 2,5\%. Jarak maksimum perangkat pemancar yang masih dapat direspon oleh penerima adalah 10 meter tanpa penghalang.
\end{abstract}

Kata kunci: home automation, hand gesture, MPU, Arduino Nano

\begin{abstract}
Home automation using recognized hand gesture has the benefit to control the household electronic appliances for handicapped patients and people with disabilities who have problems with locomotion. In previous research, a glove equipped with an accelerometer and a gyroscope sensors were used as the sensing device. People wearing this glove have problems to do other activities simultaneously so a more wearable device is needed. This proposed research developed a home automation system based on hand gesture recognition using Motion Processing Unit (MPU). The proposed device is made in the form of a wearable digital watch. The MPU sensor will identify a hand gesture particular image and send it to the Arduino Nano microcontroller. The command identified by the microcontroller will be sent to the receiver over a radio frequency module. Based on test results, this device can control home appliances using hand gestures signal as desired in specifications with $2.5 \%$ error value. The maximum reachable distance without obstacles is 10 meters.
\end{abstract}

Keywords: home automation, hand gesture, MPU, Arduino Nano 


\section{Pendahuluan}

Home automation adalah suatu sistem otomasi terintegrasi yang dapat mengontrol peralatan elektronik rumah seperti lampu, kipas angin, TV, pintu gerbang, dan perangkat elektronik lainnya [1]. Sistem ini dapat memberikan kemudahan kepada pemilik rumah untuk mengontrol peralatan rumahnya tanpa harus berjalan mendekat ke saklar. Terlebih kepada para penyandang disabilitas yang memiliki keterbatasan untuk berjalan [2]. Seiring dengan perkembangan teknologi, beberapa perangkat elektronik dapat dikontrol menggunakan remote dengan teknologi inframerah. Namun hal ini masih kurang efektif karena setiap perangkat memiliki remote tersendiri dan harus diarahkan ke perangkat yang akan dikontrol [3]. Perangkat elektronik lain yang dapat mengendalikan peralatan elektronik rumah antara lain menggunakan aplikasi atau kamera pada smartphone maupun menggunakan sarung tangan. Dalam prakteknya perangkat yang menggunakan smartphone maupun sarung tangan sering merepotkan pengguna karena harus membawabawa smartphone atau menggunakan sarung tangan yang membuat pengguna kurang leluasa bila ingin melakukan kegiatan lainnya.

Dari latar belakang masalah tersebut muncul suatu gagasan untuk mengembangkan penelitian home automation dengan sensor MEMS akselerometer dan MEMS giroskop dalam bentuk perangkat yang lebih wearable. Sensor diletakkan pada pergelangan tangan kanan dalam bentuk jam tangan digital. Ketika tangan memberikan gerakan isyarat, sensor akan membaca nilai akselerometer dan giroskop pada sumbu $x, y$, dan $z$ sehingga setiap gerakan akan menghasilkan respon sinyal/pola yang berbeda-beda. Pola tersebut kemudian diproses dan didefinisikan oleh Arduino Nano sebagai perintah yang akan dikirim melalui modul Frekuensi Radio untuk mengendalikan peralatan elektronik rumah secara nirkabel [4]. Keuntungan dari sistem ini adalah tangan kanan tetap dapat digunakan untuk melakukan kegiatan lainnya. Keuntungan lainnya adalah karena pola yang dibuat bisa banyak sehingga memungkinkan untuk mengontrol beberapa peralatan elektronik rumah sebagai pengganti beberapa remote control. Karena proses pengenalan isyarat gerakan tangan cukup singkat maka delay waktu untuk mengendalikan peralatan elektronik cukup kecil. Sistem ini tidak tergantung dari ada tidaknya jaringan internet karena menggunakan komunikasi dengan frekuensi radio. Kelemahan dari sistem ini adalah pola gerakan tangan yang sudah ditentukan pada perancangan ini harus dibiasakan atau dilatih oleh pengguna supaya dapat mengendalikan peralatan elektronik rumah dengan benar. Ukuran fisik dari alat ini masih termasuk besar sebagai digital watch. Jumlah perangkat yang dapat dikontrol adalah tiga perangkat elektronik dengan variasi kecepatan pada kipas angin dan variasi intensitas cahaya pada lampu. Jumlah pola gerakan tangan yang dibuat delapan gerakan.

\section{Kajian Pustaka}

Beberapa penelitian mengenai home automation telah dilakukan diantaranya home automation secara nirkabel menggunakan aplikasi Android [5]. Penelitian tersebut dapat mengendalikan berbagai peralatan elektronik rumah dengan satu aplikasi, namun pengguna harus selalu membawa ponsel dan harus membuka aplikasi Android, mencari dan menekan tombol yang akan digunakan untuk menyalakan atau mematikan peralatan elektronik. Penelitian lainnya adalah home automation dengan isyarat gerakan tangan menggunakan teknik image processing [6]. Pada penelitian tersebut pengguna harus menghadapkan tangan ke arah kamera saat memberikan gerakan isyarat dan juga adanya noise akibat kondisi pencahayaan dan warna latar. Apabila pengguna kurang tepat 
mengarahkan tangan dengan benar ke kamera maka tidak dapat mengendalikan peralatan listrik yang dikehendaki sehingga harus diulang. Penelitian lain yang menggunakan isyarat gerakan tangan yaitu home automation dengan sensor gerak Motion Processing Unit (MPU) berbasis Micro Electro Mechanical System (MEMS) akselerometer dan giroskop yang diletakkan pada sarung tangan. MPU membaca hand gesture dan memberikan respon sinyal tertentu. Sistem tersebut sudah cukup baik namun dimensi yang cukup besar dan peletakan sensor pada sarung tangan kurang fleksibel saat digunakan untuk melakukan aktivitas lain secara bersamaan. Pada sistem tersebut juga belum disertakan fitur untuk mengatur intensitas cahaya lampu dan kecepatan [7]. Pada [8] dirancang sebuah sistem home automation yang dapat mengendalikan peralatan elektronik dengan menggunakan suatu isyarat bentuk tangan yang diambil melalui sebuah kamera smartphone. Pola bentuk tangan kemudian dikirimkan ke program CODE pada cloud server untuk mengenali bentuknya dan kemudian mentriger suatu peralatan elektronik. Proses mengendalikan peralatan elektronik pada sistem ini terlihat cukup panjang karena melalui beberapa tahap sehingga delay menjadi masalah. Penelitian [9] mengendalikan peralatan elektronik dengan menggunakan isyarat bentuk tangan yang dipasangkan sarung tangan. Empat jari tangan kiri kecuali ibu jari pada sarung tangan dipasangkan sensor flex yang dapat berubah nilai resistansinya sesuai dengan gerakan jari tangan yang ditekuk. Data dari sensor flex diolah pada mikrokontroler Arduino dan dikirimkan ke Raspberry Pi untuk mengendalikan peralatan elektronik. Kelebihan sistem ini adalah menggunakan sensor yang lebih mudah dan dilengkapi aplikasi smartphone untuk melihat status peralatan yang dikontrol oleh pengguna maupun oleh penjaga orang tua yang menggunakannya. Selain itu disediakan basis data yang menyimpan data keadaan peralatan yang dikontrol. Kekurangan dari sistem ini adalah proses mengendalikan peralatan cukup panjang sehingga delay juga menjadi masalah dalam mengoperasikan peralatan elektronik. Penggunaan sarung tangan juga membuat pengguna tidak leluasa menggunakan tangannya untuk melakukan kegiatan lain.

\section{Metode Penelitian}

Sistem pengendali peralatan elektronik rumah berbasis gesture control ini terdiri dari perangkat pemancar dan perangkat penerima. Perangkat pemancar dibuat dalam bentuk jam tangan digital yang dilengkapi sensor Motion Processing Unit (MPU) yang merupakan sensor akurasi tinggi dengan fitur perangkat keras internal 16 bit ADC untuk setiap kanalnya [10]. Gerakan tersebut didefinisikan sebagai suatu perintah yang akan dikirimkan ke perangkat penerima melalui modul Radio Frekuensi nRF24L01. Modul ini merupakan modul komunikasi jarak jauh yang menggunakan frekuensi pita gelombang radio 2.4-2.5 GHz ISM (Industrial Scientific and Medical) [11]. Jenis komunikasi pada sistem ini yaitu komunikasi satu arah di mana perangkat pemancar akan mengirimkan data jika ada isyarat gerakan yang dideteksi oleh sensor. Pada sistem yang dibuat, gerakan tangan akan mengatur nyala mati dari sebuah lampu, perputaran dan nyala mati kipas angin dan membuka menutup pintu gerbang.

\subsection{Blok Diagram dan Skema Rangkaian Sistem}

Gambar 1 memperlihatkan diagram blok pemancar dari sistem beserta komponen penyusunnya. 


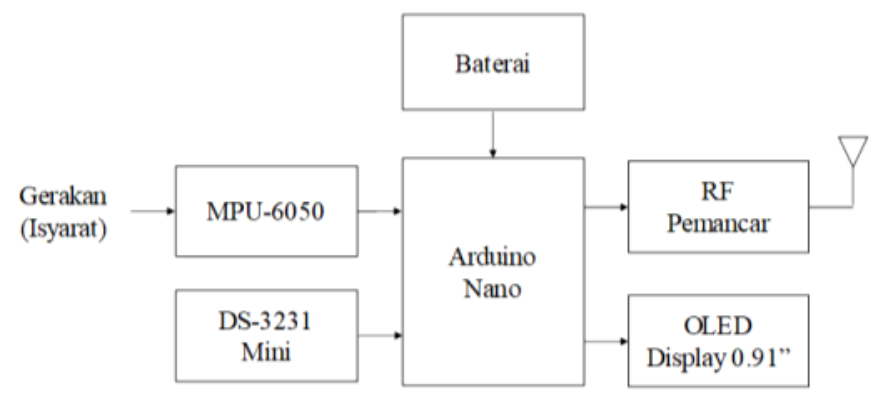

Gambar 1. Diagram blok perangkat pemancar

Bagian input pada rangkaian pemancar adalah sebuah sensor MPU-6050 (Motion Processing Unit) yang akan mendeteksi isyarat gerakan tangan. Pemilihan sensor ini karena mempunyai kemampuan anti interferensi sehingga mengurangi interaksi antara akselerometer dan giroskop, dan penggunaan dayanya rendah [12]. Fungsi dari RTC DS3231 (Real Time Clock) adalah sebagai penyimpan informasi waktu [13]. Arduino Nano sebagai prosesor memiliki ukuran yang kecil sehingga dapat diaplikasikan untuk pembuatan perangkat yang wearable [14]. Mikrokontroler tersebut akan menampilkan waktu pada OLED display pada jam tangan, mengolah sinyal dari sensor, dan mengirim data ke perangkat penerima melalui modul RF.

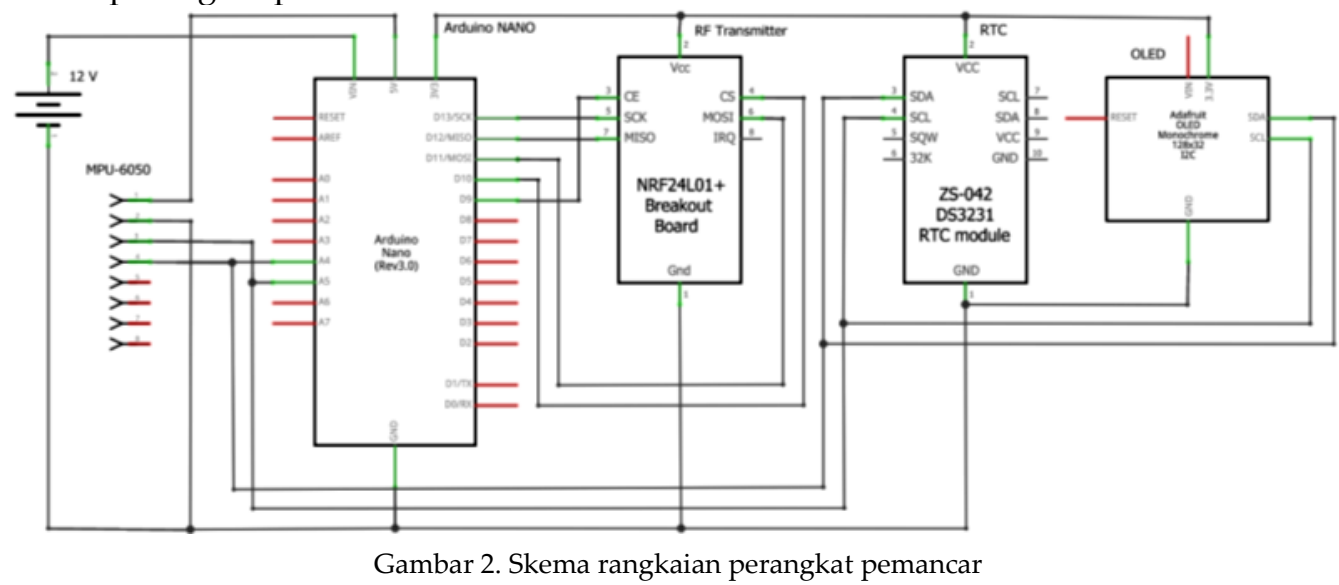

Pada Gambar 2 diperlihatkan skema rangkaian perangkat pemancar. Sensor MPU6050, modul RTC DS-3231, dan OLED menggunakan antarmuka Inter Integrated Circuit (I2C) untuk dapat berkomunikasi dengan Arduino. Ketiganya menggunakan pin yang sama yaitu pin VCC, GND ,SCL, dan SDA. Dengan membuat tiga alamat yang berbeda, Arduino dapat berkomunikasi dengan tiga perangkat dalam waktu yang bersamaan tanpa adanya interferensi data antar perangkat.

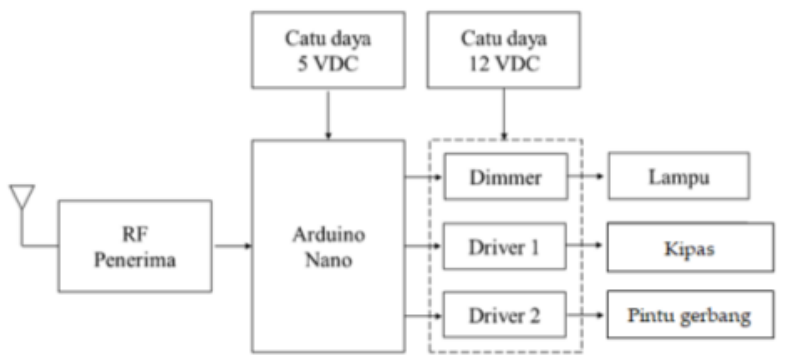

Gambar 3. Diagram blok perangkat penerima 
Gambar 3 diperlihatkan diagram blok perangkat penerima. Bagian input pada perangkat penerima adalah sebuah modul RF yang akan menerima data string dari perangkat pemancar. Arduino Nano berfungsi menerjemahkan sinyal yang diterima untuk mengaktifkan output sesuai rancangan. Bagian output terdiri dari satu buah dimmer dan dua buah driver. Dimmer akan mengendalikan lampu untuk menyala terang, redup, atau mati. Driver 1 berfungsi untuk mengatur putaran kecepatan kipas angin, sedangkan driver 2 berfungsi untuk mengatur motor stepper untuk membuka atau menutup pintu gerbang. Lampu, motor stepper pada pintu gerbang, dan kipas menggunakan catu daya 12 V. Pada Gambar 4 diperlihatkan skema rangkaian perangkat penerima.

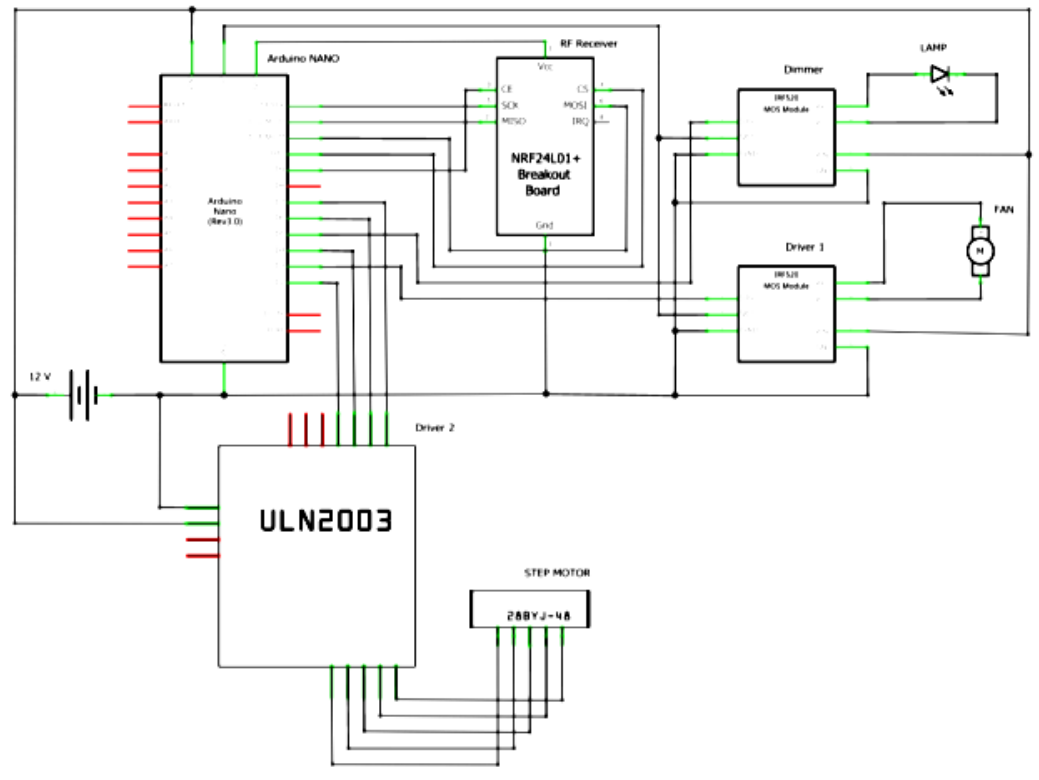

Gambar 4. Skema rangkaian perangkat penerima

Pada perangkat penerima terdapat modul NRF24L01 yang berfungsi untuk menerima data dalam bentuk data string dari perangkat pemancar secara nirkabel. Data akan diproses oleh Arduino Nano untuk menghasilkan sinyal ke aktuator sesuai dengan data yang diterima. Pada bagian output perangkat penerima terdapat satu buah modul IRF520 yang berfungsi sebagai dimmer yang mengatur intensitas cahaya lampu LED. Modul IRF520 kedua sebagai driver 1 berfungsi untuk mengatur putaran kecepatan kipas angin. Modul driver 2 ULN2003 berfungsi untuk mengatur putaran motor stepper yang akan membuka atau menutup pintu.

\subsection{Pola Gerakan Tangan}

Gerakan tangan yang dirancang dibuat dalam bentuk pola 1 sampai dengan pola 8 . Gerakan isyarat dengan masing-masing fungsinya dapat dilihat pada Tabel 1. Pola 1, 2 dan 3 digunakan untuk mengendalikan lampu. Pola 1 adalah gerakan untuk menyalakan lampu dengan terang sedangkan Pola 2 untuk menyalakan lampu dengan redup. Fungsi Pola 3 adalah untuk mematikan lampu. Pola 4 dan 5 untuk membuka dan menutup pintu gerbang. Pola 6, 7 dan 8 digunakan untuk mengendalikan kipas angin. Pola 6 untuk menyalakan kipas angin dengan kecepatan putaran rendah sedangkan Pola 7 untuk menyalakan kipas angin dengan kecepatan putaran tinggi. Pola 8 digunakan untuk mematikan kipas angin. 
Tabel 1. Isyarat gerakan tangan

\begin{tabular}{|c|c|c|c|}
\hline Pola & Gerakan & Ilustrasi & Fungsi \\
\hline 1. & $\begin{array}{l}\text { Mengayunkan tangan ke atas ( } 5 \\
\text { sampai } 10 \mathrm{~cm} \text { ) }\end{array}$ & Tampak samping & Menyalakan lampu, redup \\
\hline 2. & $\begin{array}{l}\text { Mengayunkan tangan ke atas }(>10 \\
\mathrm{cm})\end{array}$ & Tampak samping & Menyalakan lampu, terang \\
\hline 3. & $\begin{array}{l}\text { Mengayunkan tangan ke bawah (5 } \\
\text { sampai } 10 \mathrm{~cm})\end{array}$ & Tampak samping & Mematikan lampu \\
\hline 4. & $\begin{array}{l}\text { Mengayunkan tangan ke kiri (5 } \\
\text { sampai } 10 \mathrm{~cm} \text { ) }\end{array}$ & Tampak atas & Membuka gerbang \\
\hline 5. & $\begin{array}{l}\text { Mengayunkan tangan ke kanan (5 } \\
\text { sampai } 10 \mathrm{~cm} \text { ) }\end{array}$ & Tampak atas & Menutup gerbang \\
\hline 6. & $\begin{array}{l}\text { Memutar tangan searah jarum jam } \\
\text { ( } 45 \text { derajat) }\end{array}$ & & $\begin{array}{c}\text { Menyalakan kipas, } \\
\text { Kecepatan putaran rendah }\end{array}$ \\
\hline 7. & $\begin{array}{l}\text { Memutar tangan searah jarum jam } \\
\text { (90 derajat) }\end{array}$ & & $\begin{array}{l}\text { Menyalakan kipas, } \\
\text { Kecepatan putaran tinggi }\end{array}$ \\
\hline 8. & $\begin{array}{l}\text { Memutar tangan berlawanan } \\
\text { jarum jam ( } 90 \text { derajat) }\end{array}$ & & Mematikan kipas \\
\hline
\end{tabular}

Pola gerakan tangan ini dapat ditambahkan apabila ada lebih banyak perangkat elektronik yang dikontrol dengan menambahkan satu algoritma untuk tiap gerakan. Perangkat yang dikontrol dapat diganti dengan perangkat lain asalkan drivernya cocok untuk perangkat elektronik penerimanya. Bila pola gerakan tangan ini sudah diprogram maka pengguna tidak dapat mengubah pola tersebut dan harus mengikuti pola tersebut dengan cara melatih gerakan yang sudah diprogramkan.

\subsection{Diagram Alir Perangkat Pemancar dan Penerima}

Diagram alir perangkat pemancar diperlihatkan pada Gambar 5. Dari diagram alir dapat dilihat mula-mula Arduino akan membaca informasi waktu dari modul RTC dan menampilkannya pada OLED display dalam format waktu 24 jam. Kemudian Arduino membaca sinyal analog dari sensor MPU-6050 dan melakukan proses smoothing (filter frekuensi rendah) dengan menggunakan algoritma yang ada pada I2Cdev library sehingga sinyal dengan frekuensi tinggi tidak dilewatkan. Setelah melalui proses smoothing, sinyal diubah ke dalam bentuk sinyal kotak dengan membandingkan nilai sinyal terhadap threshold yang sudah ditentukan di dalam algoritma Arduino. Sinyal kotak yang dihasilkan 
kemudian dibandingkan dengan 8 pola sinyal yang merepresentasikan isyarat gerakan tangan. Jika sinyal kotak yang dihasilkan sama dengan pola 1, maka Arduino akan mengirim string yang bernilai 1 ke perangkat penerima melalui modul RF. Jika sinyal kotak yang dihasilkan sama dengan pola 2, maka Arduino akan mengirim string yang bernilai 2, dan seterusnya sampai dengan pola 8 [15]. Jika sinyal kotak yang dihasilkan tidak sama dengan kedelapan pola maka tidak ada data string yang dikirim.

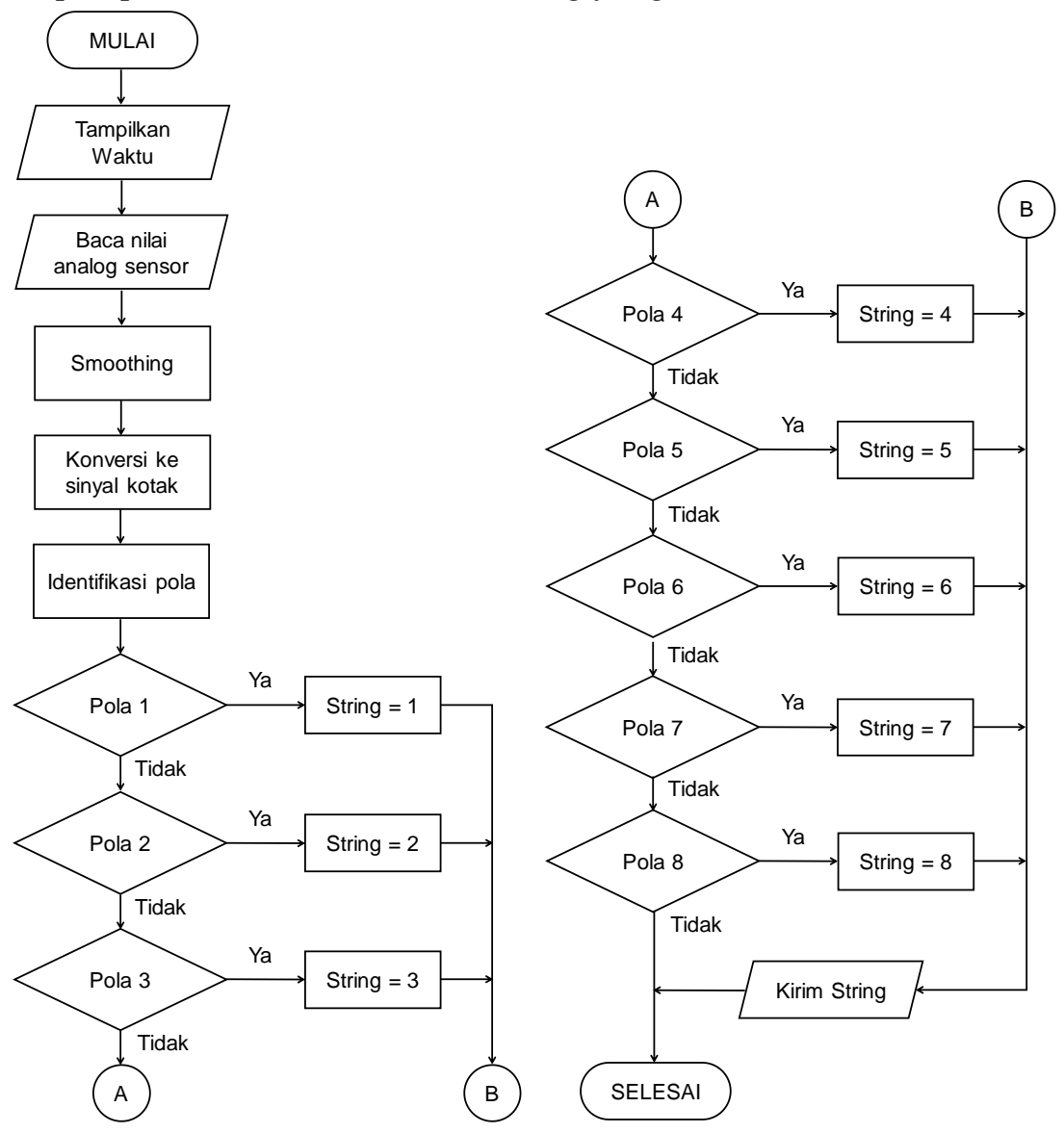

Gambar 5. Diagram alir perangkat pemancar

Berdasarkan Gambar 6, pada diagram alir perangkat penerima dapat dilihat bahwa mula-mula Arduino Nano membaca string yang diterima dari perangkat pemancar melalui modul RF. Jika string bernilai 1, maka Arduino akan menyalakan lampu dengan intensitas redup. Jika string bernilai 2, maka Arduino akan menyalakan lampu dengan intensitas terang. Jika string bernilai 3, maka Arduino akan memerintahkan lampu untuk mati. Jika string bernilai 4, Arduino akan memerintahkan gerbang untuk membuka. Jika string bernilai 5, maka gerbang akan tertutup. Jika string bernilai 6, maka kipas akan menyala dengan putaran lambat. Jika string bernilai 7, maka kipas akan menyala dengan putaran cepat. Jika string bernilai 8, Arduino akan memerintahkan driver 2 untuk mematikan kipas. Jika tidak ada string yang diterima atau string yang bernilai selain 1 sampai dengan 8, maka Arduino tidak akan memberi perintah apapun ke pin outputnya. 


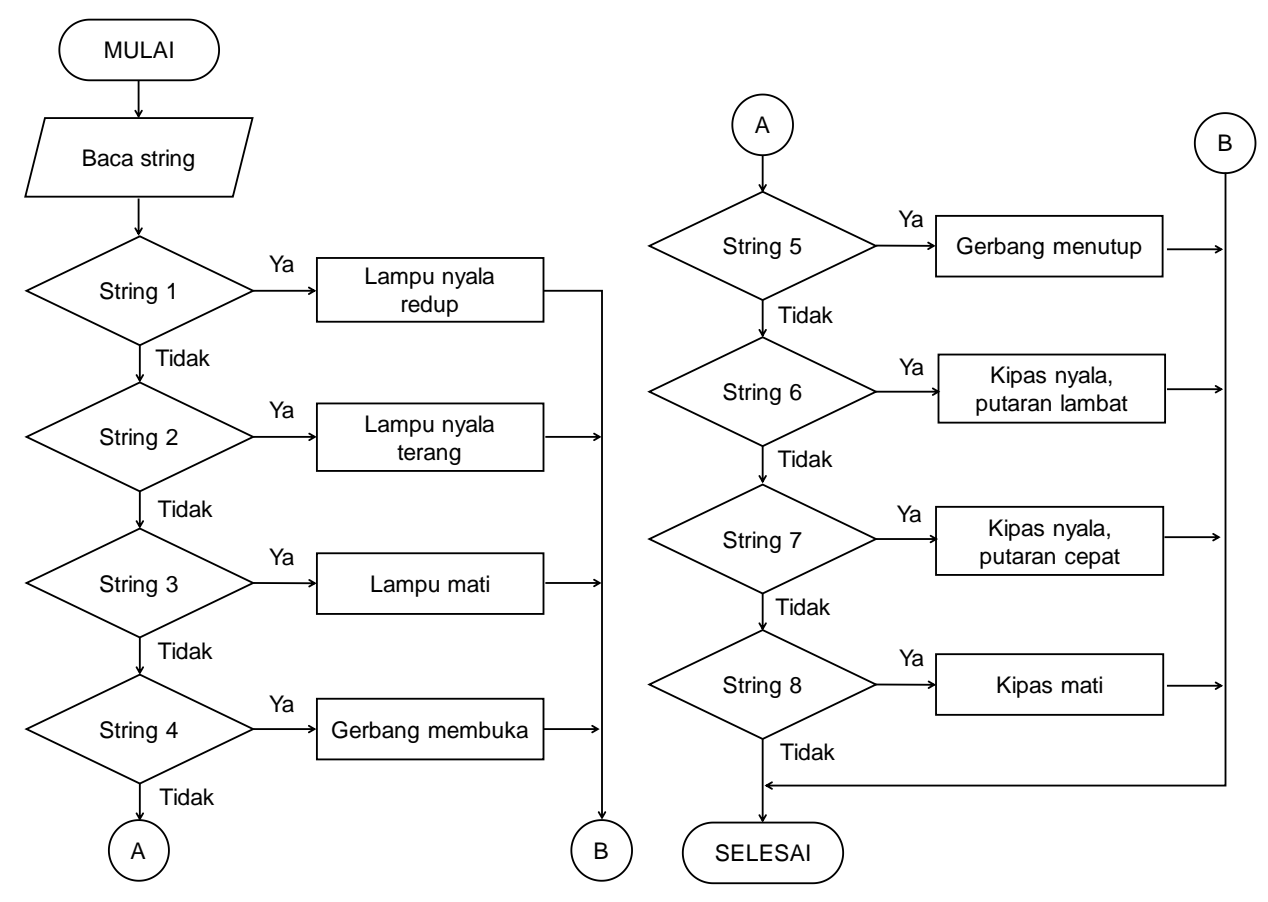

Gambar 6. Diagram alir perangkat penerima

\subsection{Pola Isyarat Gerakan Tangan}

Tabel 2 memperlihatkan rancangan pengenalan pola isyarat gerakan tangan dari sinyal yang dihasilkan oleh sensor MPU di mana sumbu vertikal merupakan nilai amplitudo sinyal, sedangkan sumbu horizontal menunjukkan waktu dalam satuan milidetik. Garis tegas berwarna menunjukkan nilai amplitudo sinyal dari akselerometer dan giroskop. Garis hitam putus-putus menunjukkan nilai amplitude threshold yang akan mengidentifikasi sinyal menjadi suatu perintah. Pengenalan pola dilakukan dengan mengidentifikasi dua sinyal akselerometer dan satu sinyal giroskop. Sinyal akselerometer menunjukkan orientasi/posisi sensor yang juga menunjukkan posisi tangan, sedangkan sinyal giroskop menunjukkan pergerakan tangan yang ditandai dengan adanya puncak dan lembah gelombang. 
Home Automation Berbasis Gesture Control Menggunakan Motion Processing Unit

Tabel 2. Pola sinyal MPU terhadap isyarat gerakan tangan

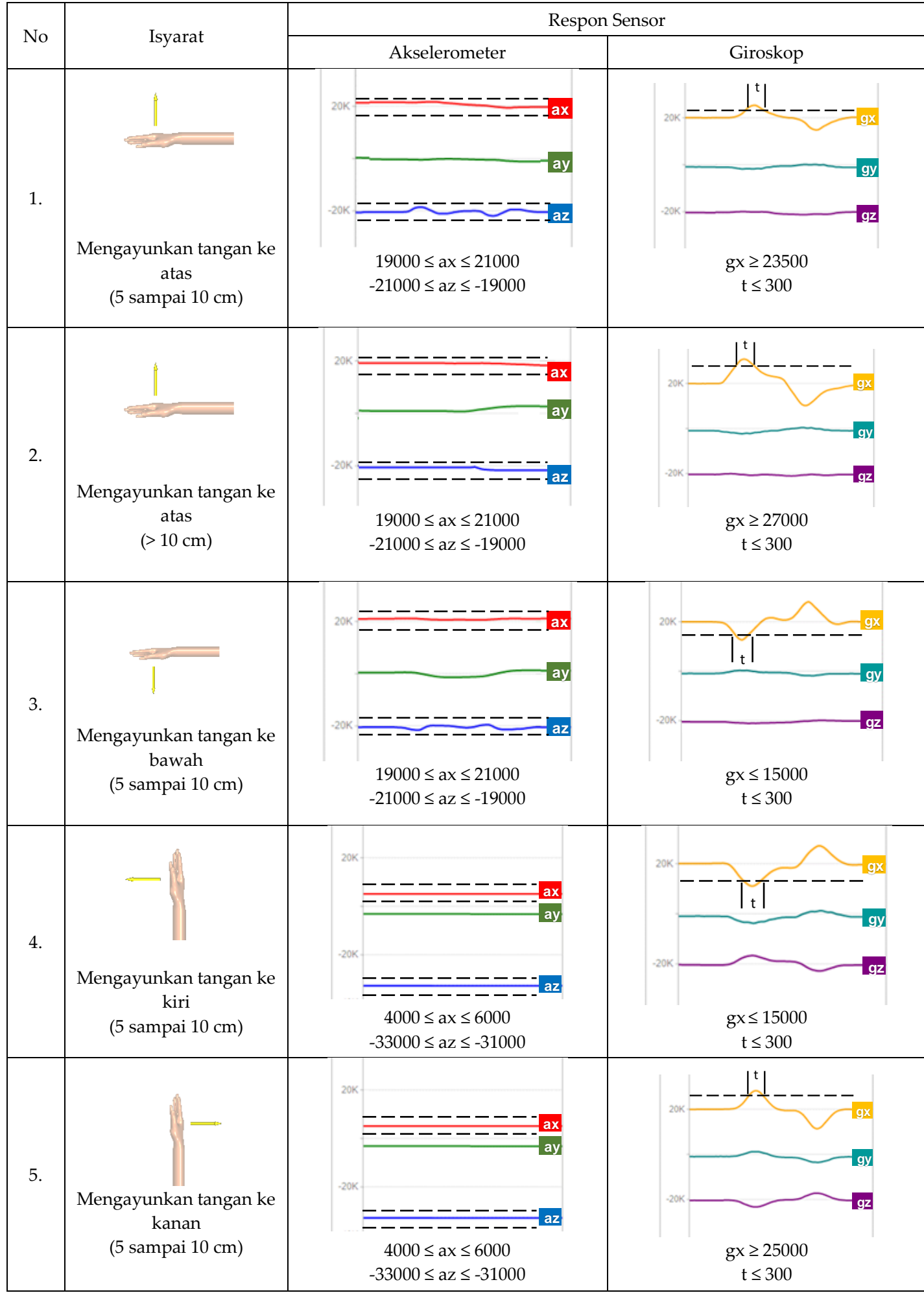


Techné Jurnal Ilmiah Elektroteknika Vol. 20 No. 2 Oktober 2021 Hal 125 - 142

Tabel 2. Pola sinyal MPU terhadap isyarat gerakan tangan (lanjutan)

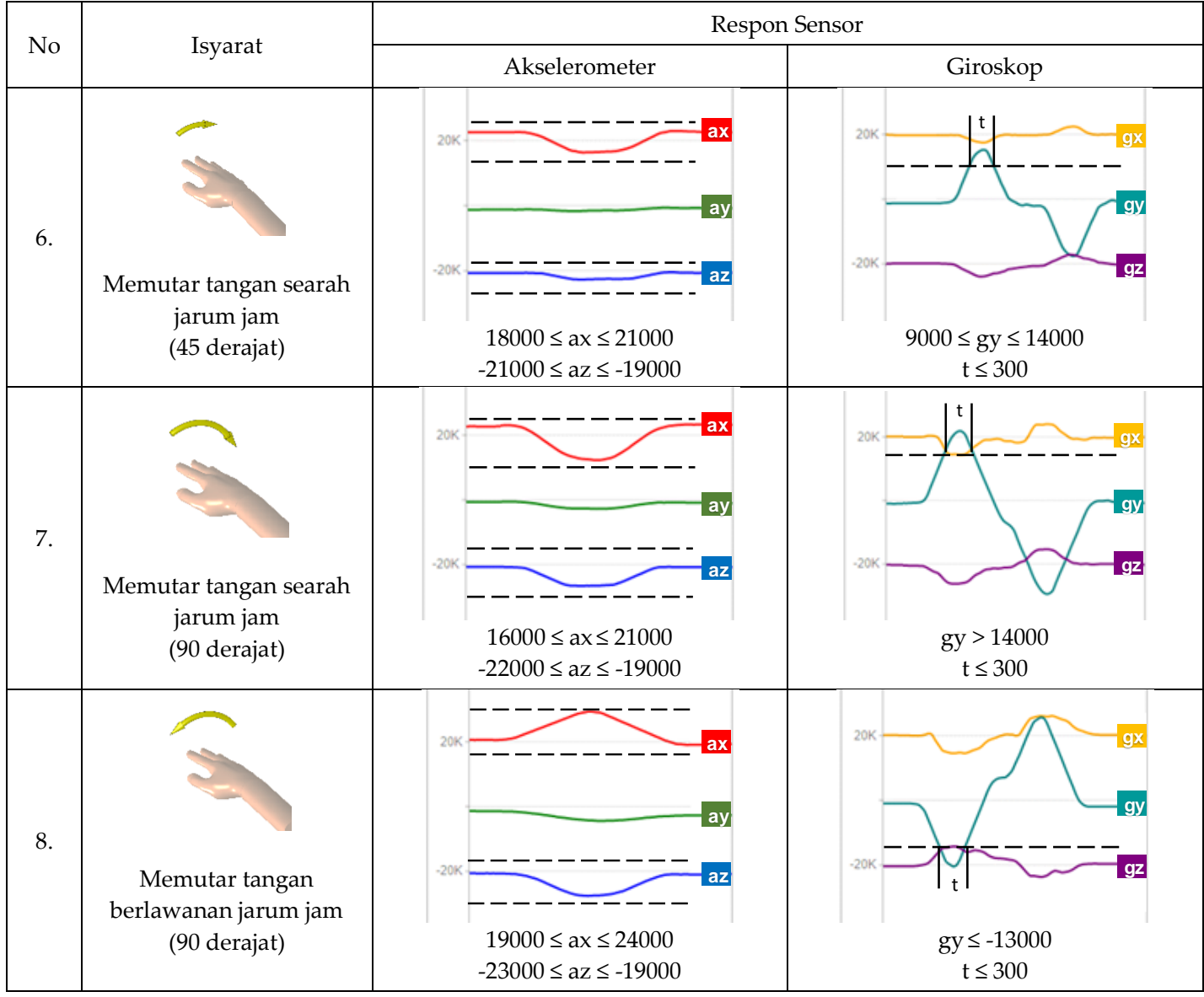

\subsection{Teknik Identifikasi Pola}

Berikut adalah proses identifikasi pola sinyal yang dihasilkan sensor MPU-6050 saat diberikan input suatu gerakan isyarat. Nilai analog sensor pada Gambar 7 hanya sebagai ilustrasi. Setiap gerakan isyarat memiliki algoritma identifikasi yang berbeda-beda.
Nilai Analog Sensor MPU-6050
Nilai Digital

Akselerometer :
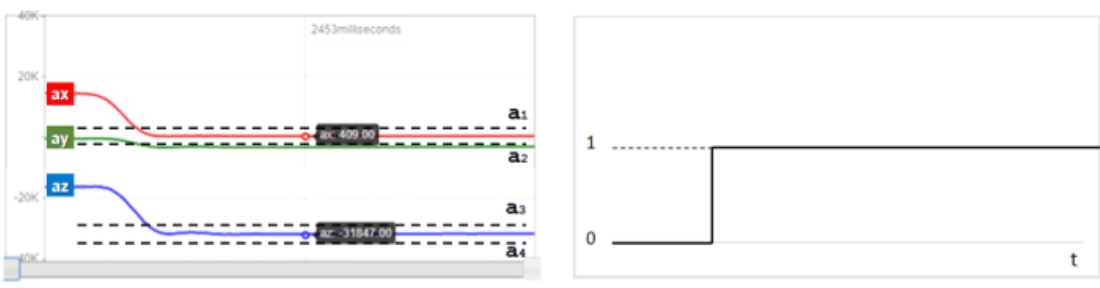

Giroskop :
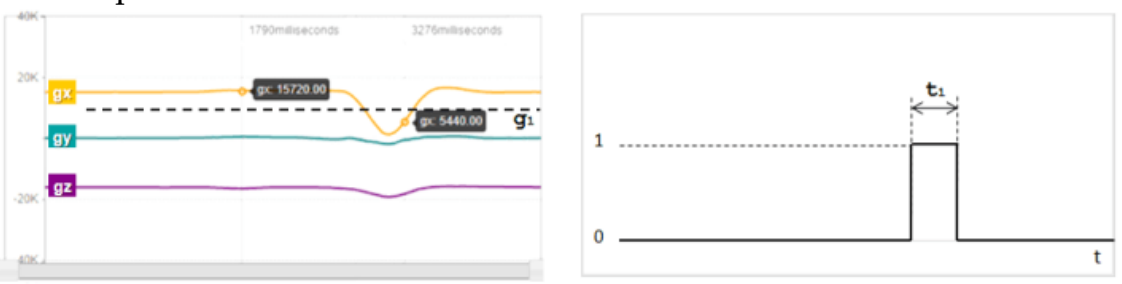

Gambar 7. Konversi nilai analog ke digital 
Setiap gerakan harus memenuhi tiga kondisi sebagai berikut :

Kondisi 1 adalah kondisi level amplitudo dari akselerometer pada sumbu $x$ dan $z$ yang dibandingkan dengan amplitudo threshold $a_{1}, a_{2}$, $a_{3}$ dan $a_{4}$.

Kondisir 2 adalah kondisi level amplitudo dari giroskop pada sumbu $\mathrm{x}$ atau sumbu $y$ yang dibandingkan dengan amplitudo threshold $g_{1}$.

Kondisi 3 adalah kondisi waktu pada giroskop untuk sinyal pada sumbu $x$ atau sumbu $y$ yang melewati batas threshold $\mathrm{tg}$.

Algoritma untuk ketiga kondisi adalah sebagai berikut:

Kondisi 1: $\quad a_{2} \leq a_{\mathrm{x}} \leq a_{1}$ dan $a_{4} \leq a_{\mathrm{z}} \leq a_{3}$

Kondisi 2: $\quad g_{x} \leq g_{1}$

Kondisi 3: $\quad t_{1} \leq t_{\mathrm{g}}$

Di mana nilai $a_{1}, a_{2}, a_{3}, a_{4}, g_{1}$, dan $t_{\mathrm{g}}$ adalah nilai threshold yang diatur di dalam algoritma Arduino. Tiap pola gerakan mempunyai nilai threshold yang berbeda. Jika kondisi 1 terpenuhi, maka nilai digital akselerometer bernilai 1 (logika high). Jika kondisi 2 terpenuhi, maka nilai digital giroskop bernilai 1. Sehingga, jika kondisi 1, kondisi 2, dan kondisi 3 terpenuhi dalam waktu yang bersamaan maka Arduino akan memutuskan perintah yang akan dikirim ke perangkat penerima.

\section{Hasil dan Pembahasan}

Hasil rancangan perangkat pemancar ditunjukkan pada Gambar 6. Dimensi board secara keseluruhan yaitu $5 \mathrm{~cm} \times 7,5 \mathrm{~cm} \times 2 \mathrm{~cm}$. Perangkat ini dilengkapi dengan gelang perekat sehingga dapat digunakan pada pergelangan tangan.

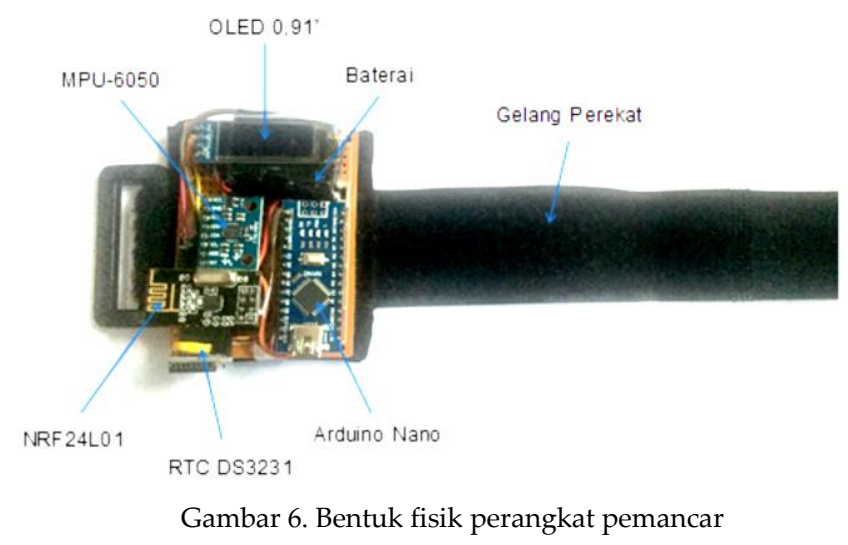

Perangkat penerima dibuat dalam bentuk miniatur dengan dimensi keseluruhan $30 \mathrm{~cm} \times 20 \mathrm{~cm} \times 9 \mathrm{~cm}$ seperti yang ditampilkan pada Gambar 7 . 


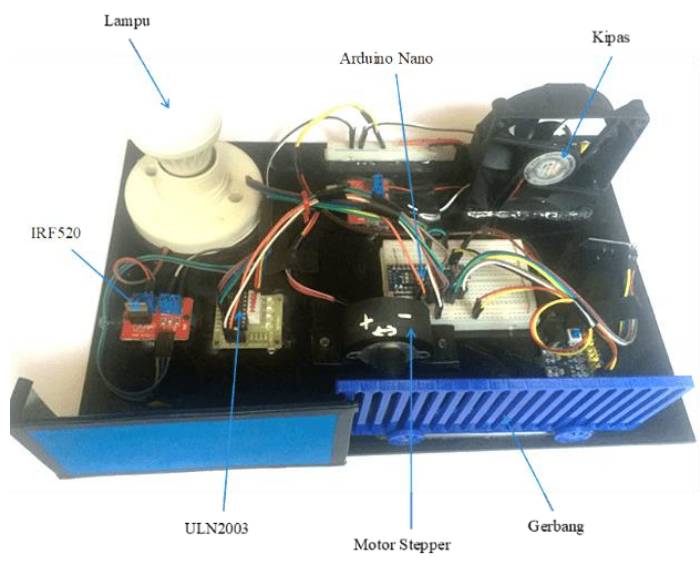

Gambar 7. Bentuk fisik perangkat penerima

\subsection{Pengujian Sinyal Sensor}

Pengujian ini dilakukan untuk mengetahui karakteristik sensor dengan mengetahui respon sinyal yang dihasilkan oleh sensor MPU-6050 ketika mengalami gerakan atau perubahan orientasi pada masing-masing sumbunya. Pada pengujian ini sensor MPU digerakkan sesuai arah sumbu $x, y$, dan $z$ pada akselerometer dan giroskop seperti yang ditunjukkan pada Gambar 8.

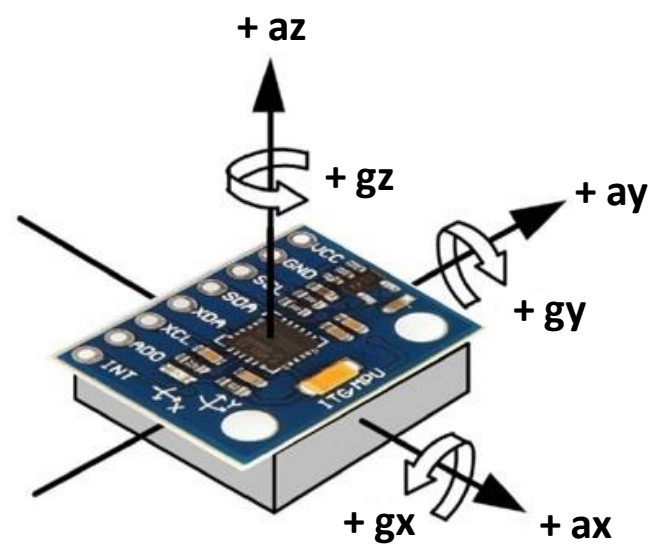

Gambar 8. Arah sumbu sensor MPU [16]

Dari Gambar 8, dapat diamati bahwa sumbu akselerometer ditandai dengan simbol ax, $a y$, dan $a z$ di mana gerakannya adalah gerakan translasi. Sumbu giroskop ditandai dengan simbol $g x, g y$, dan $g z$ di mana gerakannya merupakan gerakan rotasi. Gerakan translasi diberikan sebesar $5 \mathrm{~cm}$ sampai $10 \mathrm{~cm}$, sedangkan gerakan rotasi diberikan sebesar $45^{\circ}$ sampai $60^{\circ}$. Setiap gerakan menghasilkan respon sinyal yang dapat diamati pada aplikasi grafik realtime berbasis javascript menggunakan komunikasi serial Arduino. Data hasil pengujian sinyal sensor disajikan pada Tabel 3. 
Hasil pengujian sensor MPU

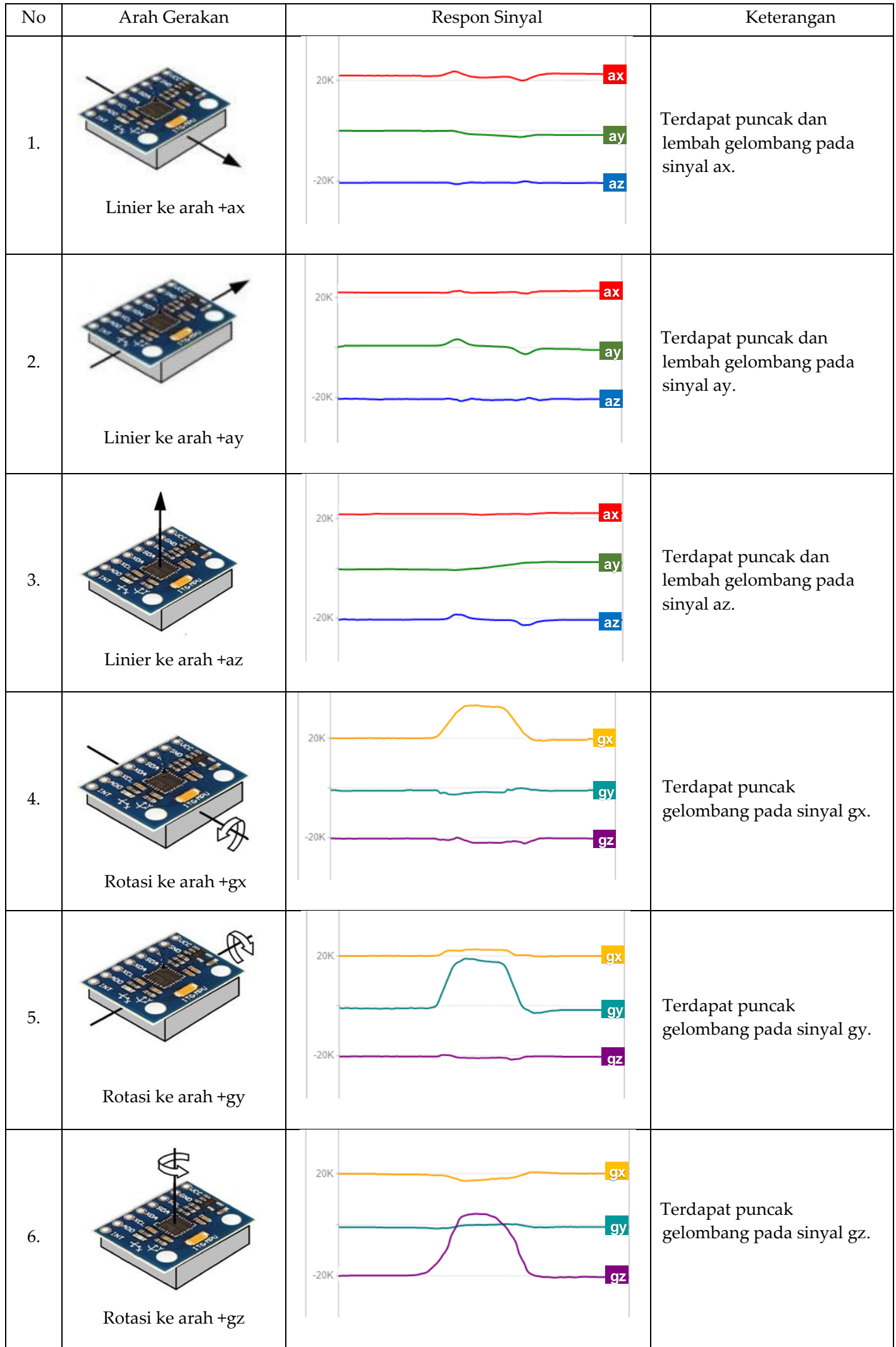


Berdasarkan Tabel 3 dapat dilihat bahwa sensor MPU menghasilkan respon sinyal sesuai dengan arah gerakan yang diberikan. Ketika diberi gerakan translasi ke arah $+a x$, $+a y$, dan $+a z$ muncul puncak dan lembah gelombang pada masing-masing sumbu namun dengan amplitudo yang kecil. Hal ini menunjukkan bahwa sensor akselerometer pada MPU memiliki sensitifitas yang cukup rendah. Ketika diberi gerakan rotasi pada arah $+g x$, $+g y$, dan $+g z$ muncul puncak gelombang pada masing-masing sumbu dengan amplitudo yang tinggi. Dari hasil pengujian sensor MPU diketahui bahwa giroskop menghasilkan respon dengan sensitifitas sensor yang lebih baik dibandingkan dengan sensitifitas akselerometer.

\subsection{Pengujian Modul Frekuensi Radio}

Pengujian modul Radio Frekuensi (RF) dilakukan untuk mengetahui seberapa jauh kemampuan komunikasi antara dua modul nRF24L01 dalam kondisi tanpa penghalang. Pengujian dilakukan dengan membuat dua buah rangkaian seperti pada Gambar 9.
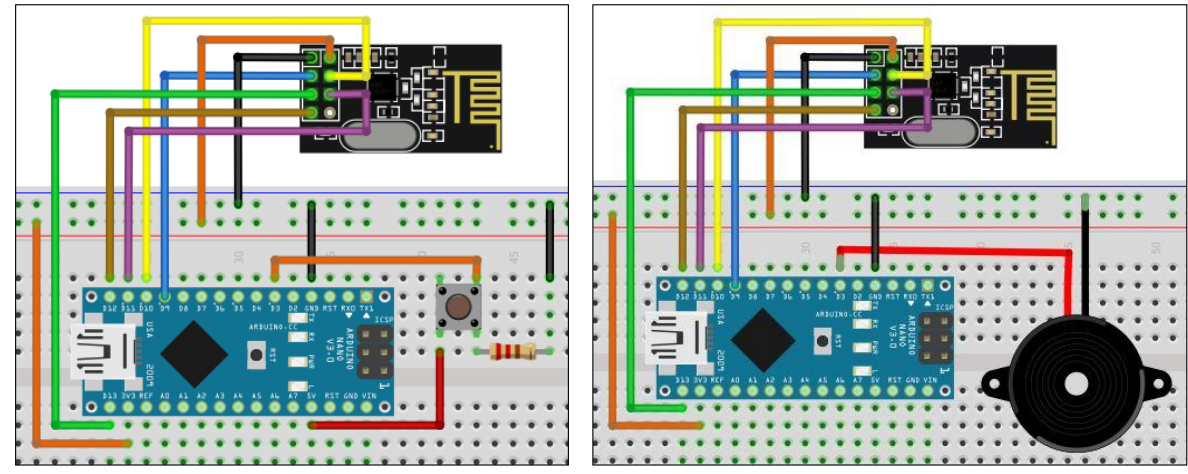

Gambar 9. Rangkaian pengujian modul RF

Rangkaian di sebelah kiri Gambar 9 adalah rangkaian pemancar yang terdiri dari Arduino Nano, push button, dan modul RF pemancar, sedangkan gambar di sebelah kanan menunjukkan rangkaian penerima yang terdiri dari Arduino Nano, buzzer, dan modul RF. Jika push button pada rangkaian pemancar ditekan, buzzer pada rangkaian penerima akan berbunyi sebagai indikasi bahwa rangkaian pemancar dan rangkaian penerima terhubung melalui modul RF. Jika push button ditekan tetapi buzzer tidak berbunyi, berarti kedua rangkaian tidak terhubung atau koneksi hilang. Pengujian ini dilakukan dengan mengubah-ubah jarak antara kedua rangkaian sehingga diketahui apakah pada tiap-tiap jarak pengujian rangkaian pemancar dan penerima masih terhubung. Data hasil pengujian dapat dilihat pada Tabel 4 .

Tabel 4. Hasil Pengujian Modul RF

\begin{tabular}{|c|c|c|}
\hline No. & Jarak $(\mathrm{m})$ & Kondisi Buzzer \\
\hline 1 & 2 & Bunyi \\
\hline 2 & 4 & Bunyi \\
\hline 3 & 6 & Bunyi \\
\hline 4 & 8 & Bunyi \\
\hline 5 & 10 & Bunyi \\
\hline 6 & 11 & Tidak bunyi \\
\hline
\end{tabular}

Berdasarkan data hasil pengujian dapat diketahui bahwa pada jarak sampai dengan 10 meter tanpa penghalang, modul RF masih dapat terhubung dan berkomunikasi 
ditandai dengan bunyi buzzer yang menunjukkan bahwa pengiriman data dari rangkaian pemancar ke rangkaian penerima telah berhasil.

\subsection{Pengujian Fungsional Sistem}

Pengujian dilakukan untuk mengetahui apakah sistem dapat bekerja dengan baik sesuai dengan spesifikasi yang dirancang, ditandai dengan aktifnya aktuator berupa lampu, kipas, dan pintu gerbang sesuai dengan input gerakan isyarat yang diberikan. Pengujian dilakukan dengan memberi gerakan-gerakan isyarat pada perangkat pemancar yang ditempatkan pada pergelangan tangan kanan seperti yang dapat dilihat pada Gambar 10. Pengamatan dilakukan pada respon peralatan elektronik rumah yang dibuat dalam bentuk miniatur. Pengujian dilakukan sebanyak sepuluh kali untuk setiap gerakan isyarat dan hasilnya disajikan pada Tabel 5.

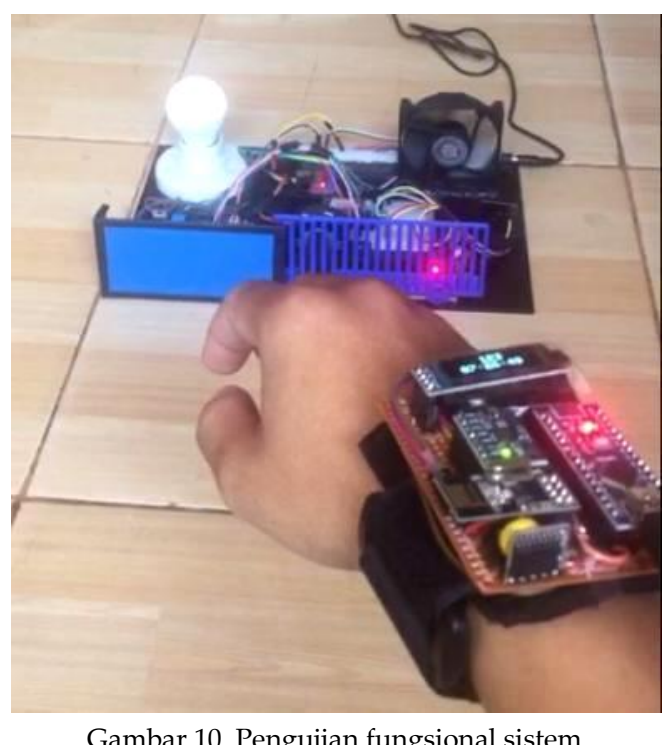

Berdasarkan data hasil pengujian pada Tabel 5, dapat diamati bahwa setiap isyarat gerakan tangan dapat memberikan perintah untuk mengendalikan peralatan elektronik. Namun, terdapat kegagalan pada isyarat 1 pengujian 5 dan isyarat 5 pengujian 2 dimana tidak terjadi respon pada aktuator. Hal ini dapat disebabkan ketidaktepatan jarak pergerakan tangan sehingga sinyal sensor tidak menghasilkan puncak atau lembah gelombang yang dibatasi threshold. Pengguna perangkat ini dituntut untuk menghafalkan dan memperkirakan besarnya pergerakan yang mampu memberikan respon pada aktuator. Dibutuhkan latihan untuk membiasakan gerakan-gerakan isyarat tersebut. Berdasarkan hasil pengujian dapat dihitung nilai persentase error yang terjadi pada fungsi sistem yaitu sebesar $2,5 \%$ sesuai perhitungan di bawah ini.

$$
\begin{aligned}
\text { Error } & =\frac{\text { Jumlah percobaan gagal }}{\text { Jumlah seluruh percobaan }} \times 100 \% \\
& =\frac{2}{80} \times 100 \% \\
& =2,5 \%
\end{aligned}
$$


Techné Jurnal Ilmiah Elektroteknika Vol. 20 No. 2 Oktober 2021 Hal 125 - 142

Tabel 5. Hasil pengujian fungsional sistem

\begin{tabular}{|c|c|c|c|c|c|}
\hline \multirow{2}{*}{ No. } & \multirow{2}{*}{ Gerakan Isyarat } & \multirow{2}{*}{ Pengujian ke- } & \multicolumn{3}{|c|}{ Respon Aktuator } \\
\hline & & & Lampu & Pintu & Kipas \\
\hline \multirow{10}{*}{1.} & \multirow{10}{*}{$\begin{array}{l}\text { Mengayunkan tangan ke atas } \\
\qquad(5 \text { sampai } 10 \mathrm{~cm})\end{array}$} & 1 & Redup & - & - \\
\hline & & 2 & Redup & - & - \\
\hline & & 3 & Redup & - & - \\
\hline & & 4 & Redup & - & - \\
\hline & & 5 & - & - & - \\
\hline & & 6 & Redup & - & - \\
\hline & & 7 & Redup & - & - \\
\hline & & 8 & Redup & - & - \\
\hline & & 9 & Redup & - & - \\
\hline & & 10 & Redup & - & - \\
\hline \multirow{10}{*}{2.} & \multirow{10}{*}{$\begin{array}{l}\text { Mengayunkan tangan ke atas } \\
\qquad(>10 \mathrm{~cm})\end{array}$} & 1 & Terang & - & - \\
\hline & & 2 & Terang & - & - \\
\hline & & 3 & Terang & - & - \\
\hline & & 4 & Terang & - & - \\
\hline & & 5 & Terang & - & - \\
\hline & & 6 & Terang & - & - \\
\hline & & 7 & Terang & - & - \\
\hline & & 8 & Terang & - & - \\
\hline & & 9 & Terang & - & - \\
\hline & & 10 & Terang & - & - \\
\hline \multirow{10}{*}{3.} & \multirow{10}{*}{$\begin{array}{c}\text { Mengayunkan tangan ke } \\
\text { bawah } \\
(5 \text { sampai } 10 \mathrm{~cm})\end{array}$} & 1 & Mati & - & - \\
\hline & & 2 & Mati & - & - \\
\hline & & 3 & Mati & - & - \\
\hline & & 4 & Mati & - & - \\
\hline & & 5 & Mati & - & - \\
\hline & & 6 & Mati & - & - \\
\hline & & 7 & Mati & - & - \\
\hline & & 8 & Mati & - & - \\
\hline & & 9 & Mati & - & - \\
\hline & & 10 & Mati & - & - \\
\hline \multirow{10}{*}{4.} & \multirow{10}{*}{$\begin{array}{l}\text { Mengayunkan tangan ke kiri } \\
\quad(5 \text { sampai } 10 \mathrm{~cm})\end{array}$} & 1 & - & Membuka & - \\
\hline & & 2 & - & Membuka & - \\
\hline & & 3 & - & Membuka & - \\
\hline & & 4 & - & Membuka & - \\
\hline & & 5 & - & Membuka & - \\
\hline & & 6 & - & Membuka & - \\
\hline & & 7 & - & Membuka & - \\
\hline & & 8 & - & Membuka & - \\
\hline & & 9 & - & Membuka & - \\
\hline & & 10 & - & Membuka & - \\
\hline \multirow{10}{*}{5.} & \multirow{10}{*}{$\begin{array}{c}\text { Mengayunkan tangan ke } \\
\text { kanan } \\
(5 \text { sampai } 10 \mathrm{~cm})\end{array}$} & 1 & - & Menutup & - \\
\hline & & 2 & - & - & - \\
\hline & & 3 & - & Menutup & - \\
\hline & & 4 & - & Menutup & - \\
\hline & & 5 & - & Menutup & - \\
\hline & & 6 & - & Menutup & - \\
\hline & & 7 & - & Menutup & - \\
\hline & & 8 & - & Menutup & - \\
\hline & & 9 & - & Menutup & - \\
\hline & & 10 & - & Menutup & - \\
\hline
\end{tabular}


Tabel 5. Hasil pengujian fungsional sistem (lanjutan)

\begin{tabular}{|c|c|c|c|c|c|}
\hline \multirow{2}{*}{ No. } & \multirow{2}{*}{ Gerakan Isyarat } & \multirow{2}{*}{ Pengujian ke- } & \multicolumn{3}{|c|}{ Respon Aktuator } \\
\hline & & & Lampu & Pintu & Kipas \\
\hline \multirow{10}{*}{6.} & \multirow{10}{*}{$\begin{array}{l}\text { Memutar tangan searah jarum } \\
\text { jam (45 derajat) }\end{array}$} & 1 & - & - & Lambat \\
\hline & & 2 & - & - & Lambat \\
\hline & & 3 & - & - & Lambat \\
\hline & & 4 & - & - & Lambat \\
\hline & & 5 & - & - & Lambat \\
\hline & & 6 & - & - & Lambat \\
\hline & & 7 & - & - & Lambat \\
\hline & & 8 & - & - & Lambat \\
\hline & & 9 & - & - & Lambat \\
\hline & & 10 & - & - & Lambat \\
\hline \multirow{10}{*}{7.} & \multirow{10}{*}{$\begin{array}{l}\text { Memutar tangan searah jarum } \\
\text { jam (90 derajat) }\end{array}$} & 1 & - & - & Cepat \\
\hline & & 2 & - & - & Cepat \\
\hline & & 3 & - & - & Cepat \\
\hline & & 4 & - & - & Cepat \\
\hline & & 5 & - & - & Cepat \\
\hline & & 6 & - & - & Cepat \\
\hline & & 7 & - & - & Cepat \\
\hline & & 8 & - & - & Cepat \\
\hline & & 9 & - & - & Cepat \\
\hline & & 10 & - & - & Cepat \\
\hline \multirow{10}{*}{8.} & \multirow{10}{*}{$\begin{array}{l}\text { Memutar tangan berlawanan } \\
\text { jarum jam (90 derajat) }\end{array}$} & 1 & - & - & Mati \\
\hline & & 2 & - & - & Mati \\
\hline & & 3 & - & - & Mati \\
\hline & & 4 & - & - & Mati \\
\hline & & 5 & - & - & Mati \\
\hline & & 6 & - & - & Mati \\
\hline & & 7 & - & - & Mati \\
\hline & & 8 & - & - & Mati \\
\hline & & 9 & - & - & Mati \\
\hline & & 10 & - & - & Mati \\
\hline
\end{tabular}

\section{Kesimpulan}

Telah dibuat suatu sistem home automation dengan isyarat gerakan tangan menggunakan sensor MPU yang terdiri dari perangkat pemancar dan perangkat penerima. Perangkat yang dibuat telah diuji dan dapat mengendalikan peralatan elektronik rumah dengan isyarat gerakan tangan sesuai spesifikasi yang diinginkan dengan nilai error sebesar 2,5\%. Jarak maksimum perangkat pemancar yang masih dapat direspon oleh penerima adalah $10 \mathrm{~m}$ tanpa penghalang. Perlu adanya latihan gerakan tangan sesuai perancangan oleh pengguna perangkat ini sehingga alat ini dapat berfungsi baik. Penelitian ini dapat dikembangkan lebih lanjut dengan perbaikan seperti membuat desain perangkat keras pemancar dalam suatu single board yang terintegrasi agar ukuran fisik perangkat menjadi lebih kecil sehingga lebih nyaman digunakan. Sistem ini juga dapat dikembangkan untuk mengontrol lebih banyak perangkat elektronik dengan menambah gerakan. Lebih lanjut sistem dapat menggunakan teach mode yaitu mode yang dapat merekam gerakan yang dilakukan pengguna yang kemudian dapat dipanggil untuk mengontrol peralatan tambahan. 


\section{Daftar Pustaka}

[1] H. Thiruvengada. et al., "System for controlling home automation system using body movements," U.S. Patent US20130204408A1, Aug. 8, 2013.

[2] S. Jeet, V. Dhillon, H.S. Bhatia, "Radio Frequency Home Appliance Control Based on Head Tracking and Voice Control for Disabled Person," in International Conference on Communication Systems and Network Technologies (CSNT), 2015.

[3] R.A. Cockrell. et al., "Home automation system and method including remote media access," U.S. Patent US 8,230,466 B2, Jul. 24, 2012.

[4] L.A. Roberts. et al., "Gesture activated home appliance," U.S. Patent US 6,937,742 B2, Aug. 30, 2007.

[5] B. Kajal, V. Aayushi, and P. Romil, "Wireless Home automation System Using Android Application," Int. J. Adv. Eng. Res. Dev., vol. 4.72, no. Special Issue SIEICON2017, p. 6, 2017.

[6] H. S. Yoon. et al., "Method and apparatus for recognizing gesture in image processing system," U.S. Patent US8014567B2, Sept. 6, 2011.

[7] A. N. Abhijit M., J. John, and M. B. M. , ShabasBasheer, "Hand Gesture Based Home Automation," Int. J. Adv. Res. Electr. Electron. Instrum. Eng., vol. 6, no. 3, p. 5, 2017.

[8] D. Jain. et al, "Smart Home Automation System using Hand Gestures, IoT and Service Oriented Architecture," Int. J. Adv. Sci. Technol., vol. 29, no. C3, pp. 6059-6067, 2020.

[9] S. Kshirsagar. et al, "IoT Enabled Gesture-Controlled Home Automation for Disabled and Elderly," in Proceedings of the Fourth International Conference on Computing Methodologies and Communication (ICCMC 2020), pp. 821-, doi: 10.1109/ICCMC48092.2020.ICCMC-000152.

[10] InvenSense, "MPU-6000and MPU-6050Register Map and Descriptions Revision 4.2," MPU-6050 datasheet, Aug. 2013. [Online]. Available : https:// invensense.tdk.com/wpcontent/uploads/2015/02/MPU-6000-Datasheet1.pdf

[11] S. Nordic, "Single chip $2.4 \mathrm{GHz}$ Transciever nRF24L01," 2006. [Online]. Available: https://html.alldatasheet.com/htmlpdf/1243924/ETC1/NRF24L01/112/1/NRF24L01.html.

[12] T. Xu. et al., "The real-time elderly fall posture identifying scheme with wearable sensors," Int. J. Distrib. Sens. Networks, vol. 15, no. 11, 2019, doi: https://doi.org/10.1177/1550147719885616.

[13] S. DALLAS, “Extremely Accurate I2C-IntegratedRTC/TCXO/Crystal,” Datasheet, 2005. [Online]. Available: https://www.alldatasheet.com/datasheetpdf/pdf/112132/DALLAS/DS3231.html.

[14] C. Commons Atributtion ShareAlike 3.0 Licence, "Getting Started with the Arduino Nano," 2018. [Online]. Available: https://www. arduino.cc/en/Guide/ArduinoNano.

[15] H. Yan. et al, "Monitoring user activity using wearable motion sensing device," U.S. Patent US10347108B2, Jul. 9, 2019.

[16] areacom.altervista.org, "Arduino MPU6050 GY521: Giroscopio e accelerometro," 2015. [Online]. Available: https://areacom.altervista.org/arduino-mpu6050-gy521giroscopio-e-accelerometro/. 